\title{
Przedsiębiorczość jako czynnik rozwoju terenów wiejskich województwa świętokrzyskiego
}

\section{Entrepreneurship as a Factor of Development of Rural Areas of the Świętokrzyskie Voivodeship}

Streszczenie: Przedsiębiorczość jest istotnym czynnikiem rozwoju gospodarczego wsi, stanowi bowiem szansę dla poprawy warunków życia w sensie ekonomicznym i społecznym. Powszechne już zjawisko dywersyfikacji gospodarstw rolnych wpłynęło znacząco na rozwój wielofunkcyjny wsi i aktywności jej mieszkańców. W rozwoju przedsiębiorczości kluczowe znaczenie mają małe, rodzinne firmy (takie jak: sklepy, drobna wytwórczość, usługi) oraz turystyka wiejska (w tym agro- i ekoturystyka). Spadek dochodów z działalności rolniczej, brak możliwości pracy w ośrodkach miejskich oraz niski poziom życia wpłynęły na potrzebę poszukiwania alternatywnych źródeł dochodów. Działalność na rachunek własny przyczynia się do wykorzystania nadmiaru siły roboczej, niwelowania bezrobocia, $w$ tym ukrytego, oraz większych możliwości stabilizacji, poprawy sytuacji materialnej rolników i mieszkańców wsi. Uruchomienie coraz większych przedsięwzięć gospodarczych o charakterze pozarolniczym i rolniczym niesie wiele korzystnych przeobrażeń tak pod względem poziomu wykształcenia, życia, statusu społecznego, jak i świadomości oraz zamożności mieszkańców wsi. Na terenach wiejskich województwa świętokrzyskiego funkcjonują firmy, które napotykają na wiele trudności, np. brak wykwalifikowanej kadry, kapitału, czy trudności w kwestii niskooprocentowanych kredytów. Istotne znaczenie dla wspierania przedsiębiorczości na wsi mają działania władz lokalnych. Od ich kompetencji i zaangażowania we wspieranie przedsiębiorców oraz pobudzanie aktywności mieszkańców zależą dalszy rozwój gospodarczy i poziom życia na wsi. Celem artykułu jest analiza przedsiębiorczości jako czynnika, który istotnie wpływa na rozwój obszarów wiejskich regionu świętokrzyskiego. W trakcie pracy wykorzystano analizę materiału statystyki masowej dla małych i średnich firm, wybrane wskaźniki społeczno-ekonomiczne oraz informacje o działaniach w kierunku rozwoju przedsiębiorczości na terenach wiejskich w ramach wsparcia finansowego z Regionalnego Programu Operacyjnego Województwa Świętokrzyskiego 2007-2013 (RPOWŚ). W pracy zastosowano podstawowe metody statystyczne oparte na grupowaniu i prezentacji tabelaryczno-graficznej oraz wskaźniki ukazujące dynamikę zmian. Na podstawie literatury przedmiotu, wyników z analiz i źródeł faktograficznych podjęto próbę ukazania wpływu przedsiębiorczości na terenach wiejskich regionu świętokrzyskiego.

Abstract: Entrepreneurship is an important element of economic development of rural areas as it creates prospects for better living conditions, both in economic and social sense. Nowadays a common phenomenon of diversification of agricultural farms has considerably affected multifunctional development of rural areas and their inhabitants activity. Small, family firms (e.g. shops, craft, services, etc.) and 
tourism in rural areas (including agritourism and ecotourism) play a crucial role in the development of entrepreneurship. A drop in profits from agricultural activity, lack of urban employment and poor living standard has emphasized the significance of alternative income sources. Own business activity uses labor force surplus, it also lowers unemployment, including hidden unemployment, and gives chances for stability, better living conditions for farmers and inhabitants of rural areas. The emergence of larger and larger agricultural and non-agricultural investments contributes to numerous positive changes in terms of education level, living conditions, social status and awareness as well as the wealth of inhabitants of rural areas. In rural areas of the Swietokrzyskie Voivodeship there are companies planning to expand their businesses, even though many of them have no chances for expansion based on their own resources. They face numerous problems, e.g. lack of qualified employees, insufficient capital or difficulties in obtaining credits with low interests. Steps taken by local authorities are crucial for the development of entrepreneurship in rural areas. Further economic development and living standards in rural areas depend on authorities' competence, commitment in supporting businessmen and encouragement to stimulate economic activity of inhabitants. The goal of the study was to describe entrepreneurship as an important factor influencing the development of rural areas of the Swietokrzyskie region. It analyzed statistical data concerning small and medium companies, selected socio-economic indices and activities promoting entrepreneurship in rural areas within the financial support from the Regional Operational Program of the Swietokrzyskie Voivodeship 2007-2013 (Regionalny Program Operacyjny Województwa Świętokrzyskiego 2007-2013 - RPOWŚ). The study employed basic statistical methods based on cluster analysis, table and graphic presentation, and it described indices concerning the dynamics of changes. Based on professional literature, analyses and actual data sources it aimed at presenting the influence of entrepreneurship on rural areas of the Swiętokrzyskie region.

Słowa kluczowe: mikrofirmy; obszary wiejskie; podmioty gospodarcze; pozarolnicza działalność gospodarcza; przedsiębiorczość

Key words: economic entities; entrepreneurship; micro-enterprises; non-agricultural business activity; rural areas

Otrzymano: 10 listopada 2015

Received: 10 November 2015

Zaakceptowano: 2 marca 2016

Accepted: 2 March 2016

\section{Sugerowana cytacja/Suggested citation:}

Kiniorska I., Wrońska-Kiczor J. (2015). Przedsiębiorczość jako czynnik rozwoju terenów wiejskich województwa świętokrzyskiego. Przedsiębiorczość - Edukacja, 12, 36-51.

\section{Wstęp}

Przemiany polityczne i społeczno-gospodarcze w kraju na przełomie wieków znalazły swoje odbicie także w rozwoju wsi i rolnictwa. Zachodzące zjawiska wpłynęły na zmniejszenie ekonomicznego znaczenia rolnictwa jako sektora gospodarki, co ograniczyło dochody ludności rolniczej. Procesy restrukturyzacyjne rolnictwa doprowadziły do wielu zmian na wsi, m.in.: przemiany modelu z rozwoju monofunkcyjnego do wielofunkcyjnego, przyspieszonej dezagraryzacji, wzrostu bezrobocia utajonego i rozwoju rolnictwa opartego na nowoczesnych technologiach. W wyniku zmniejszania się opłacalności rolnictwa wzrosło zainteresowanie działalnością pozarolniczą, pracą najemną, pracą na własny rachunek, która staje się coraz powszechniejszym źródłem dochodów. Tworzenie na wsi warunków powstawania 
pozarolniczych miejsc pracy jest jednym z najpoważniejszych wyzwań dla polityki rozwoju regionu świętokrzyskiego (Wrońska-Kiczor, 2013).

Dokonujące się przeobrażenia silnie oddziaływały na sektor gospodarki państwowej. Restrukturyzacja przemysłu ciężkiego, metalowego i zbrojeniowego w województwie kieleckim, dokonana w latach 1990-1999, pozbawiła pracy 74 tys. osób. Z badań (Jarosińskiego, Trafiałek, 2014), wynika, że w latach 1989-2010 pracę straciło około 250 tys. ludzi, w tym głównie w grupie dwuzawodowej. Były to zwłaszcza osoby zbędne na wsi z północnej części regionu. Z danych PSR 1996 wynika, że grupa ta liczyła 95,3 tys. osób, w tym 41,3 tys. stanowiła podgrupa osób całkowicie zbędnych, a 54 tys. - częściowo zbędnych. W latach 1990-2012, skomercjalizowano 33\% przedsiębiorstw sektora państwowego metodą bezpośrednią, sprywatyzowano 31\%, a likwidacji poddano 35\%, w tym zlikwidowano 16,4\% (Wrońska-Kiczor, 2014).

Utrata stałej pracy poza gospodarstwem wymusiła szukanie innych źródeł dochodów na wsi, co z czasem doprowadziło do tworzenia mikro-, małych, średnich i dużych firm z działalnością pozarolniczą.

Rozwój MŚP przyczynia się do zmian strukturalnych, tak w rolnictwie, jak i w środowisku wiejskim (Duczkowska-Piasecka, 1997). W rolnictwie wzmacniają się takie procesy, jak: modernizacja, koncentracja, polaryzacja i specyfikacja gospodarstw, co wpływa na przemiany struktury agrarnej oraz kierunki produkcji rolnej. Z kolei w środowisku wiejskim dokonują się zmiany m.in. w strukturze społeczno-zawodowej ludności i ich źródłach dochodów, następuje też wzrost wydajności pracy i możliwości awansu społecznego oraz przyspieszenie procesów urbanizacyjnych.

Z przedsiębiorczością nierozerwalnie łączy się postawa przedsiębiorcza, która rozumiana jest przez wielu autorów (Makieła, 2008; Rachwał, 2005; Strojny, 2010: Zioło, 2008) jako specyficzny rodzaj aktywności, kreatywności i inicjatywy człowieka, z predyspozycjami cech osobowości, która wyraża się w jego twórczym działaniu, skierowanym do zapewnienia racjonalnej i efektywnej koordynacji zapasów gospodarczych, co w rezultacie daje możliwość osiągania racjonalnego gospodarowania i efektywności ekonomicznej. Przedsiębiorczość jest zarówno siłą społeczno-ekonomiczną o wymiarze ekonomicznym, jak i osobowym, społecznym i kulturowym (Jaremczuk, 2003). Rozwój przedsiębiorczości i aktywizacji gospodarczej, zdaniem Zioło (2007), dokonuje się w danym otoczeniu, w którym kształtują się procesy rozwoju społeczno-gospodarczego. Przez różnorodne powiązania te układy mogą generować określone czynniki rozwoju i wpływać na zmianę ich pozycji konkurencyjnej przez zmianę wewnętrznych uwarunkowań. Czynniki te mogą być wzmocnione impulsami lub osłabione barierami działającymi w skali lokalnej, do których można zaliczyć m.in.: zasoby kapitałowe ludności, chłonność rynku, niezaspokojone potrzeby i aspiracje społeczności lokalnej, stan środowiska naturalnego, rozmiary bezrobocia, stopień wyposażenia w infrastrukturę lokalną, kompetencje i aktywność władz samorządowych, szybkość rozprzestrzeniania się i przyswajania innowacji, a także tradycje w zakresie rozwoju prywatnej inicjatywy (Kamińska, 1994; 1996).

\section{Charakterystyka obszaru badań}

Tereny wiejskie województwa świętokrzyskiego zajmują 94,3\% powierzchni regionu, a zamieszkuje je ponad 700,4 tys. ludności (BDL, 2014) i należą do grupy najsłabiej rozwiniętych gospodarczo w kraju. Niska ich lokata na tle kraju wynika przede wszystkim ze struktury 
gospodarki, w której przeważają mało efektywne działy produkcji (udział w przemyśle krajowym $2,6 \%$, a w produkcji sprzedanej 2,3\%, co daje 14 miejsce), przy niewielkich nakładach inwestycyjnych - 2,6\% (11 miejsce) z niedoinwestowaniem firm, co ogranicza w nich m.in. zatrudnienie. Według Eurostatu, udział sektora przedsiębiorstw w PKB w Polsce jest na tym samym poziomie, co przeciętna dla krajów Unii Europejskiej (47,8\% w 2011 r.). Wskaźnik syntetyczny rozwoju przedsiębiorczości, liczba aktywnych MŚP na 1000 osób oraz dochody i przeciętne wynagrodzenie lokują województwo na odległej pozycji w kraju, co świadczy o niższym poziomie aktywności gospodarczej i dzielących dysproporcjach między regionami (tab. 1).

Warunki życia na terenach wiejskich są znaczne zróżnicowanie. Wieś świętokrzyska charakteryzuje się występowaniem barier rozwojowych na wielu płaszczyznach (Wrońska-Kiczor, 2013).

Do niekorzystnych zjawisk społecznych należą zarówno brak zatrudnienia poza rolnictwem, duże bezrobocie, w tym ukryte, jak i niewystarczające wyposażenie w placówki służby zdrowia oraz utrzymujące się zubożenie. Na płaszczyźnie środowiskowo-infrastrukturalnej główną barierą jest niski poziom rozwoju infrastruktury, zwłaszcza infrastruktury kanalizacyjnej. Niekorzystna sytuacja panuje na terenach usytuowanych blisko granic województwa, szczególnie w części północno-zachodniej i północno-wschodniej. Analiza rozkładu syntetycznego wskaźnika warunków życia wskazała na pewne zależności, wynikające także z położenia badanych gmin (ryc. 1).

Na kształtowanie poziomu życia mieszkańców wsi świętokrzyskiej, obok pełnionych funkcji, duży wpływ ma położenie w pobliżu ośrodków miejskich o charakterze subregionalnym. Stąd najwyższy poziom życia odnotowano w rejonach położonych w bezpośrednim zapleczu miast. Ponadto ośrodki usytuowane w pobliżu głównych szlaków komunikacyjnych $\mathrm{z}$ reguły mają korzystniejsze parametry demograficzne i społeczne, a także lepiej adoptują się do mechanizmów gospodarki rynkowej. Na obszarach tych notuje się niższą stopę bezrobocia, większą aktywność społeczności lokalnej oraz niższy wskaźnik osób starszych (Kiniorska, 2010). Niższy poziom życia występuje na terenach z przewagą funkcji rolniczej i położonych peryferyjnie, charakteryzujących się mało korzystnymi uwarunkowaniami ekonomicznymi wynikającymi z restrukturyzacji gospodarki.

Początki rozwoju MŚP datuje się na lata 90. XX w. MŚP tworzyły głównie rodziny, przy ośrodkach przemysłowych, przeważnie tam, gdzie następowała likwidacja zakładów. W regionie kieleckim w 1990 r. liczba podmiotów gospodarczych wyniosła ponad 3 tys. i wzrosła w 1998 r. do 64947 (ponad 20-krotnie). Od 1999 r. w woj. świętokrzyskim ich liczebność wzrosła o 36,7\%, w tym o 64,8\% na wsi (tab. 2) (Jarosiński, Trafiałek, 2014: 126-136).

W strukturze branżowej działalności gospodarczej największy odsetek stanowiły jednostki zajmujące się handlem i naprawami. W systemie gospodarki regionalnej ważne miejsce zajmują działalność produkcyjna, budownictwo, obsługa firm i nieruchomości i transport. W aktywności gospodarczej regionu dominuje sektor prywatny skupiający około 107 tys. firm, tj. 97\% ich ogólnej liczby, co potwierdzają dane zawarte w tabeli 3.

Wśród przedsiębiorstw istotne miejsce należy do mikroprzedsiębiorstw zatrudniających do 9 osób i małych, w których pracuje od 10 do 49 osób. W badanym 15-leciu wzrósł ich udział o $37,4 \%$, a małych przedsiębiorstw o $33 \%$, natomiast o $32 \%$ zmniejszył się udział przedsiębiorstw dużych, zatrudniających ponad 249 osób.

Nakłady inwestycyjne przedsiębiorstw w badanych latach wzrosły o ponad 43,2\%. Najwięcej inwestycji prowadziły duże firmy (tab. 4). 
Tab. 1. MŚP według wybranych wskaźników w województwie na tle kraju w 2012 r.

\begin{tabular}{|l|c|c|c|}
\hline \multicolumn{1}{|c|}{ Wyszczególnienie } & Województwo & Polska & Lokata \\
\hline Wartość syntetycznego wskaźnika przedsiębiorczości & 42,05 & 88,46 & 12 \\
\hline Liczba aktywnych MŚP /1000 mieszkańców & 37,22 & 46,50 & 11 \\
\hline Liczba nowo powstałych i zlikwidowanych & $\begin{array}{r}10,6 \\
\text { przedsiębiorstw/1000 mieszkańców }\end{array}$ & $\begin{array}{r}13,42 \\
8,06\end{array}$ & 13 \\
\hline $\begin{array}{l}\text { Przychody przedsiębiorstw aktywnych z sektora } \\
\text { MŚP na przedsiębiorstwo (mln zł) }\end{array}$ & 0,93 & 1,16 & 13 \\
\hline Nakłady inwestycyjne MŚP/przedsiębiorstwo (tys. zł) & 46,12 & 41,57 & 3 \\
\hline $\begin{array}{l}\text { Przeciętne wynagrodzenie w aktywnych } \\
\text { przedsiębiorstwach: małych (0-49) i średnich (50-249) }\end{array}$ & 2262 & 2704 & 11 \\
\hline
\end{tabular}

Źródło: Raport o stanie sektora MŚP w latach 2012-2013 (2014: 61-70)

Ryc. 1. Przestrzenne zróżnicowanie terenów wiejskich w województwie świętokrzyskim według klas poziomu życia

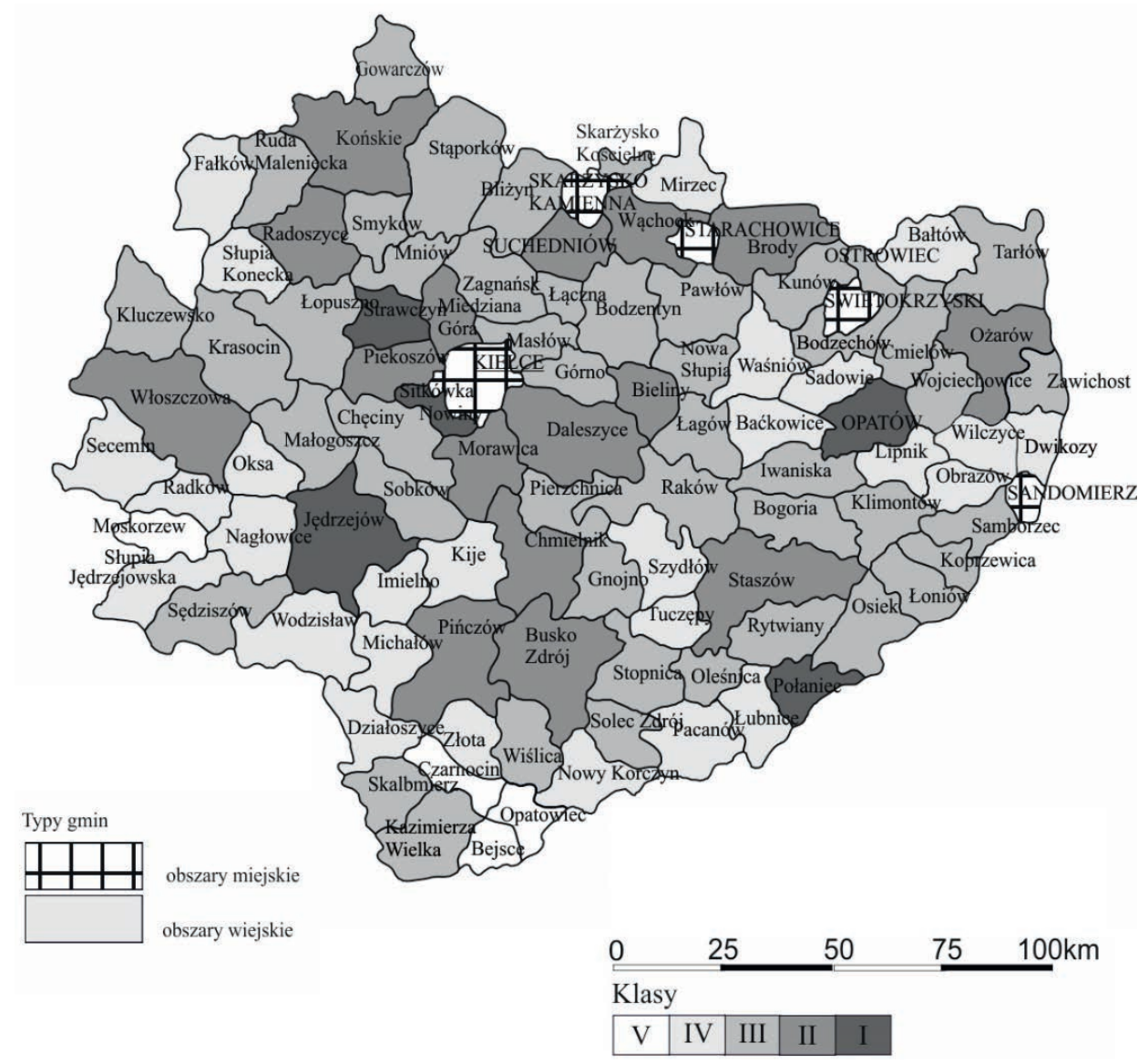

Źródło: opracowanie własne na podstawie danych z Banku Danych Lokalnych GUS z 2011 r. 
Tab. 2. Podmioty gospodarki narodowej ogółem wg REGON-u w woj. świętokrzyskim w latach 1999-2014

\begin{tabular}{|c|c|c|c|c|c|c|}
\hline \multirow{2}{*}{$\begin{array}{l}\text { Liczba i struktura podmiotów } \\
\text { gospodarczych wg sekcji }\end{array}$} & \multicolumn{5}{|c|}{ Lata } & \multirow{2}{*}{$\begin{array}{c}1999= \\
=100\end{array}$} \\
\hline & 1999 & 2004 & 2010 & 2012 & 2014 & \\
\hline Ogółem & 81112,0 & 103116,0 & 108715,0 & 108068,0 & 110130,0 & 136,7 \\
\hline Udział sektora publicznego & 4,0 & 3,7 & 3,1 & 3,3 & 2,9 & 72,5 \\
\hline Udział sektora prywatnego & 96,0 & 96,3 & 96,9 & 96,7 & 97,1 & 101,2 \\
\hline w tym: w miastach & 55548,0 & 68884,0 & 69632,0 & 68019,0 & 67995,0 & 122,4 \\
\hline w tym: na wsi & 25564,0 & 34232,0 & 39083,0 & 40049,0 & 42135,0 & 164,8 \\
\hline Przetwórstwo przemysłowe [\%] & 10,6 & 9,4 & 9,1 & 9,7 & 10,1 & $-0,5$ \\
\hline Budownictwo [\%] & 11,2 & 11,0 & 13,3 & 13,3 & 13,0 & 1,8 \\
\hline Obsługa firm i nieruchomości [\%] & 9,4 & 12,1 & 11,9 & 11,8 & 12,0 & 2,8 \\
\hline Handel-naprawy [\%] & 40,8 & 38,6 & 34,3 & 32,5 & 31,1 & $-9,7$ \\
\hline $\begin{array}{l}\text { Transport, gospodarka } \\
\text { samochodowa [\%] }\end{array}$ & 8,1 & 7,3 & 7,0 & 6,6 & 6,5 & $-1,6$ \\
\hline
\end{tabular}

Źródło: obliczono na podstawie roczników statystycznych woj. świętokrzyskiego za lata 1999-2014

Tab. 3. Liczba, struktura i dynamika podmiotów gospodarczych wg liczby zatrudnionych w woj. świętokrzyskim w latach 1999-2014

\begin{tabular}{|c|c|c|c|c|c|c|c|c|c|}
\hline \multirow{2}{*}{ Wyszczególnienie } & \multicolumn{8}{|c|}{ Lata } & \multirow{3}{*}{$\begin{array}{l}1999= \\
=100\end{array}$} \\
\hline & \multicolumn{2}{|c|}{1999} & \multicolumn{2}{|c|}{2005} & \multicolumn{2}{|c|}{2010} & \multicolumn{2}{|c|}{2014} & \\
\hline \multirow{2}{*}{$\begin{array}{l}\text { Ogółem, w tym } \\
\text { zatrudniające: }\end{array}$} & liczba & {$[\%]$} & liczba & {$[\%]$} & liczba & [\%] & liczba & [\%] & \\
\hline & 81112 & 100,0 & 104416 & 100,0 & 108715 & 100,0 & 110130 & 100,0 & 135,8 \\
\hline do 9 osób & 77109 & 95,1 & 99439 & 95,2 & 103228 & 94,9 & 105140 & 95,4 & 136,3 \\
\hline od 10 do 49 osób & 3023 & 3,7 & 4045 & 3,9 & 4512 & 4,2 & 4020 & 3,7 & 133,0 \\
\hline od 50 do 249 osób & 803 & 1,0 & 803 & 0,8 & 849 & 0,8 & 850 & 0,8 & 105,8 \\
\hline powyżej 249 osób & 177 & 0,2 & 129 & 0,1 & 126 & 0,1 & 120 & 0,1 & 67,8 \\
\hline
\end{tabular}

Źródło: obliczono na podstawie Raportów o stanie sektora MŚP w latach 1999-2012 i danych z BDL za 2014 r.

Tab. 4. Nakłady inwestycyjne w przedsiębiorstwach woj. świętokrzyskiego w latach 2007-2011

\begin{tabular}{|l|c|c|c|c|c|}
\hline \multicolumn{1}{|c|}{ Wyszczególnienie } & Ogółem & $\mathbf{0 - 9}$ & $\mathbf{1 0 - 4 9}$ & $\mathbf{5 0 - 2 4 9}$ & \multicolumn{1}{c|}{$\mathbf{2 5 0}$} \\
\hline Nakłady [zł] 2007 & 2868479 & 928730 & 410045 & 666412 & 863412 \\
2011 & 4108671 & 868818 & 286401 & 820773 & 2132679 \\
\hline Udział firm regionu 2007 & 100,00 & 32,38 & 14,29 & 23,23 & 30,10 \\
2011 & 100,00 & 21,15 & 6,97 & 19,98 & 51,91 \\
\hline
\end{tabular}

Źródło: obliczono na podstawie Raportów o stanie sektora MŚP w latach 2004-2012

W strukturze inwestycji MŚP największy udział miały podmioty lokowane w sekcjach: przetwórstwo przemysłowe (20\%), działalność obsługi nieruchomości (16,27\%), a także wytwarzanie i zaopatrywanie w energię elektryczną i gaz (11,43\%). W sektorze przedsiębiorstw wartość wydatków na badania i rozwój jest o wiele niższa w stosunku do średniej krajowej. Podobnie jest z nakładami na działalność badawczo-rozwojową, których udział stanowił 0,33\% (na mieszkańca przypadało 95 zł, a relacja do PKB wynosiła 0,38\% w 2011 r.) nakładów poniesionych na ten cel w skali kraju, co świadczy o dystansie między najbardziej konkurencyjnymi regionami. Mikro- i małe firmy w regionie są mniej innowacyjne w porównaniu z ich resztą w kraju. 
Do założenia i prowadzenia firmy około $2 / 3$ środków finansowych pochodzi z własnych zaoszczędzonych zasobów właściciela. Pozostałe źródła stanowią środki budżetowe i zagraniczne oraz kredyty, pożyczki krajowe i inne (tab. 5).

Obecnie najpopularniejszym źródłem pozyskiwania funduszy są kredyty bankowe. Zaciąganie kredytów przez MŚP w regionie jest nadal niewielkie, co wynika z braku zaufania do banku, a także z ostrożności przed zadłużaniem się firmy na wypadek jej upadku. Istotnym czynnikiem determinującym wybór źródeł finansowania dla MŚP jest ich dostępność wynikająca z sytuacji finansowej firmy. Większość z nich korzysta z mieszanych form finansowania, łącząc własne wewnętrzne i zewnętrzne środki z obcymi.

Największą grupę tworzą podmioty osób fizycznych zajmujących się działalnością gospodarczą. Stanowią one 76,9\% ogółu zarejestrowanych w REGON, w tym na wsi 61,5\% (BDL, 2014). W regionie $w$ analizowanych latach zanotowano wzrost zarejestrowanych podmiotów na 10 tys. osób tak ogółem o 68,8\% i na obszarach wiejskich o 97\%, jak i w grupie osób fizycznych ogółem o $45 \%$, a na wsi o 45,3\%. Ponad dwukrotny ich wzrost zanotowano w powiatach skarżyskim i starachowickim, co prezentuje tabela 6 .

W badanych latach udział podmiotów gospodarczych wzrósł o 45\%. Najwięcej z nich (ogółem 958/10 tys. osób, a na terenach wiejskich 789/10 tys. osób) ulokowano na terenach powiatu skarżyskiego, a najmniej w powiatach: kazimierskim, sandomierskim i ostrowieckim. Analizując wskaźnik przedsiębiorczości według gmin, stwierdzić należy, że był zróżnicowany (ryc. 2).

Ryc. 2. Przestrzenne zróżnicowanie wskaźnika przedsiębiorczości na terenach wiejskich woj. świętokrzyskiego

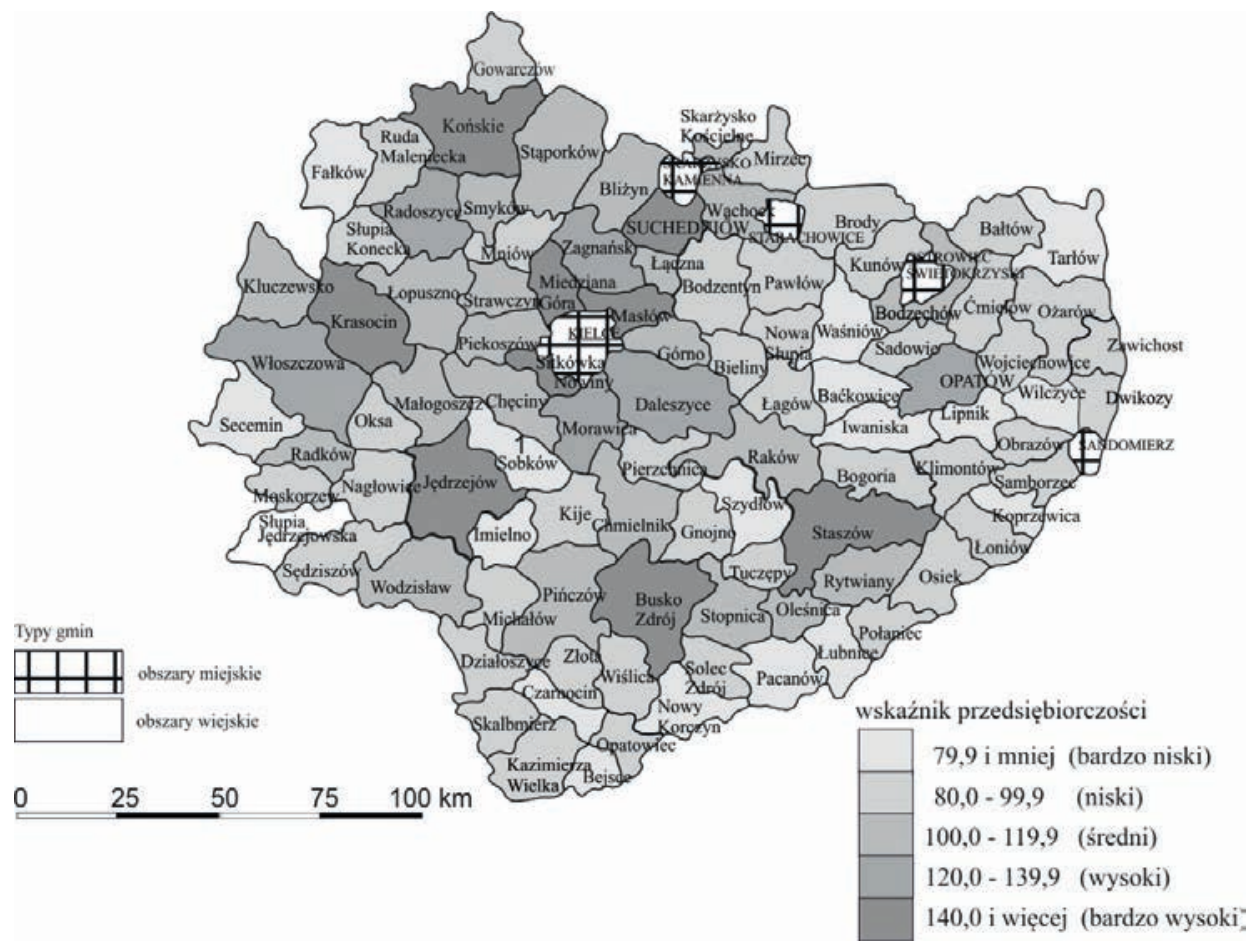

Źródło: opracowanie własne na podstawie danych z Banku Danych Lokalnych GUS z 2014 r. 
Tab. 5. Struktura źródeł finansowania inwestycji MŚP wg pracujących w woj. świętokrzyskim w latach: 2004, 2008, 2011

\begin{tabular}{|l|r|r|r|r|}
\hline \multicolumn{1}{|c|}{ Źródła finansowania } & Ogółem & $\mathbf{0 - 4 9}$ & $\mathbf{5 0 - 2 4 9}$ & $>\mathbf{2 5 0}$ \\
\hline Środki własne 2004 & 71,45 & 58,65 & 74,53 & 74,16 \\
2008 & 85,43 & 81,21 & 64,95 & 93,47 \\
2011 & 70,51 & 66,66 & 70,77 & 71,11 \\
\hline Środki budżetowe 2004 & 2,29 & 0,88 & 2,29 & 2,78 \\
2008 & 3,31 & 3,21 & 3,65 & 3,20 \\
2011 & 5,38 & 7,44 & 4,50 & 5,43 \\
\hline Kredyty i pożyczki krajowe 2004 & 10,40 & 25,23 & 11,88 & 4,27 \\
2008 & 7,34 & 15,11 & 22,37 & 0,87 \\
2011 & 15,05 & 19,63 & 12,01 & 15,71 \\
\hline Środki zagraniczne 2004 & 8,42 & 5,62 & 1,39 & 13,58 \\
2008 & 0,58 & 0,23 & 1,23 & 0,39 \\
2011 & 5,19 & 3,52 & 7,85 & 4,18 \\
\hline Pozostałe 2004 & 7,44 & 9,62 & 9,91 & 5,20 \\
2008 & 3,34 & 0,24 & 4,15 & 2,07 \\
2011 & 3,87 & 2,75 & 4,88 & 3,59 \\
\hline
\end{tabular}

Źródło: obliczono na podstawie Raportów o stanie sektora MŚP w latach 2004-2013

Tab. 6. Dynamika liczby podmiotów gospodarczych osób fizycznych w powiatach woj. świętokrzyskiego w roku 1999, 2004, 2014

\begin{tabular}{|l|c|c|c|c|c|c|c|c|}
\hline \multirow{2}{*}{ Wyszczególnienie } & \multicolumn{4}{|c|}{$\begin{array}{c}\text { Podmioty gospodarcze wg systemu } \\
\text { REGON [10 tys. os.] }\end{array}$} & \multicolumn{4}{c|}{$\begin{array}{c}\text { Osoby fizyczne prowadzące } \\
\text { działalność gospodarczą [10 tys. os.] }\end{array}$} \\
\cline { 2 - 10 } & $\mathbf{1 9 9 9}$ & $\mathbf{2 0 0 4}$ & $\mathbf{2 0 1 4}$ & $\mathbf{1 9 9 9}=\mathbf{1 0 0}$ & $\mathbf{1 9 9 9}$ & $\mathbf{2 0 0 4}$ & $\mathbf{2 0 1 4}$ & $\mathbf{1 9 9 9 = 1 0 0}$ \\
\hline Ogółem region & 613 & 800 & 1035 & 168,8 & 549 & 648 & 796 & 145,0 \\
\hline Obszary wiejskie & 455 & 598 & 898 & 197,1 & 380 & 493 & 552 & 145,3 \\
\hline buski & 532 & 665 & 754 & 141,7 & 442 & 548 & 606 & 137,1 \\
\hline jędrzejowski & 462 & 634 & 693 & 150,0 & 382 & 519 & 546 & 142,9 \\
\hline kazimierski & 275 & 389 & 522 & 189,8 & 211 & 277 & 373 & 176,8 \\
\hline kielecki & 454 & 590 & 743 & 163,6 & 384 & 499 & 623 & 162,2 \\
\hline konecki & 591 & 746 & 769 & 130,1 & 506 & 628 & 613 & 121,1 \\
\hline opatowski & 461 & 571 & 602 & 130,6 & 379 & 453 & 454 & 119,8 \\
\hline ostrowiecki & 358 & 552 & 595 & 166,2 & 295 & 464 & 481 & 163,0 \\
\hline pińczowski & 437 & 553 & 629 & 143,9 & 346 & 432 & 458 & 132,4 \\
\hline sandomierski & 350 & 471 & 528 & 150,9 & 289 & 381 & 391 & 135,3 \\
\hline skarżyski & 473 & 603 & 958 & 202,5 & 403 & 514 & 789 & 195,8 \\
\hline starachowicki & 357 & 466 & 719 & 201,4 & 306 & 403 & 593 & 193,8 \\
\hline staszowski & 508 & 673 & 697 & 137,2 & 426 & 548 & 548 & 128,6 \\
\hline włoszczowski & 442 & 609 & 771 & 174,4 & 361 & 498 & 618 & 171,2 \\
\hline
\end{tabular}

Źródło: obliczono na podstawie danych z Banku Danych Lokalnych GUS za lata 1999, 2004 i 2014 
Największy odsetek stanowiły gminy o niskiej (44,3\%) i średniej (23,7\%) wartości wskaźnika przedsiębiorczości. Korzystniejsze warunki do prowadzenia działalności gospodarczej występują na obszarach położonych w bliskim sąsiedztwie Kielc i siedzib powiatów. Niskimi wartościami wskaźnika odznaczały się gminy typowo rolnicze, ze słabo rozwiniętymi funkcjami usługowymi i niedoinwestowaniem infrastrukturalnym. Pośredni wpływ może mieć również położenie, np. peryferyjne w stosunku do miast, poza zaznaczonymi szlakami komunikacyjnymi.

Liczba podmiotów gospodarczych osób fizycznych w rejestrze REGON wg sekcji PKD na terenach wiejskich w powiatach województwa w latach 2012-2014 była zróżnicowana. W strukturze podmiotów gospodarczych sektora małych i średnich firm, obok działalności handlowej, istotną rolę odgrywają przetwórstwo przemysłowe oraz budownictwo, które w regionie należy do branży o wieloletnich tradycjach. Według RSP $2010 \mathrm{w}$ regionie było ponad 103 tys. indywidualnych gospodarstw rolnych, które użytkowały obszar 550,6 tys. ha użytków rolnych. Głównie na rynek produkowało 54,2\% jednostek prowadzących działalność rolniczą. Najczęściej były to gospodarstwa z powiatów: sandomierskiego - 82,8\%, kazimierskiego 78,4\% i opatowskiego - 73,8\% (tab. 7) (Charakterystyka..., 2012: 20).

Z badań J. Wrońskiej-Kiczor (2013) wynika, że wg PSR 2002 najwięcej gospodarstw produkowało na własne potrzeby głównie w subregionach: ostrowiecko-starachowicko-skarżyskim (75\%), kieleckim (69,4\%) i konecko-włoszczowskim (58,7\%). Gospodarstw produkujących na rynek najwięcej odnotowano w subregionach opatowsko-sandomierskim $(23,8 \%)$ i jędrzejowsko-pińczowskim (19,8\%). Około połowa z nich (40\%) prowadziła produkcję wielokierunkową, przy czym liczniejsze były grupy zajmujące się chowem trzody chlewnej, produkcją ziemniaków, owoców i warzyw, zwłaszcza w subregionach: busko-staszowskim jędrzejowsko-pińczowskim, kieleckim, konecko-włoszczowskim. Wielokierunkowość produkcji wynikała ze specyfiki upraw roślinnych dających rolnikom poczucie bezpieczeństwa zbytu. Średnio gospodarstwo rolne z produkcji towarowej uzyskiwało około 9,4 tys. zł. Wartość produkcji towarowej na jedno gospodarstwo była zróżnicowana i wahała się średnio od 5 tys. zł w ostrowiecko-starachowicko-skarżyskim do 15 tys. zł w kazimierskim. Niską wartość produkcji towarowej przypadającą na 1 pełnozatrudnionego (4,4 tys. zł-5,5 tys. zł), zanotowano w subregionach głównie o funkcji przemysłowo-rolniczej, a wyższą (7,7 tys. zł-8,7 tys. zł) w subregionach o funkcji rolniczej.

Mimo wielu zmian zachodzących pod wpływem restrukturyzacji w rolnictwie, proces poprawy siły ekonomicznej gospodarstw rolnych województwa był powolny. Głównym czynnikiem osłabiającym ich konkurencyjność na rynku jest nadal znaczne rozdrobnienie i rozdrobnienie działek, położenie w większości na obszarach o niesprzyjających warunkach do gospodarowania, jak również niska wydajność pracy i niski stopień zorganizowania producentów rolnych. Dla poprawy konkurencyjności istotne znaczenie będzie miało tempo zmian struktury obszarowej gospodarstw przez większy obrót ziemią (m.in. dzierżawę) lub scalenie gruntów. W subregionach był znacznie zróżnicowany poziom intensywności organizacji rolnictwa: od rolnictwa ekstensywnego - subregion konecko-włoszczowski oraz kielecki - do mało intensywnego - ostrowiecko-starachowicko-skarżyski, busko-staszowski i jędrzejowsko-pińczowski - do średnio intensywnego - opatowsko-sandomierski - i do wysoko intensywnego - kazimierski. Wartość współczynnika określającego poziom intensywności organizacji produkcji roślinnej była zróżnicowana i wahała się od 77 pkt poziomu ekstensywnego do 183,5 pkt, tj. bardzo wysoko intensywnego. Wartość tę wyznaczały subregiony: konecko-włoszczowski i kazimierski. W organizacji produkcji zwierzęcej w pięciu subregionach poziom był ekstensywny, mało intensywny wystąpił w subregionie jędrzejowsko-pińczowskim, a średnio intensywny stwierdzono tylko w subregionie kazimierskim. 


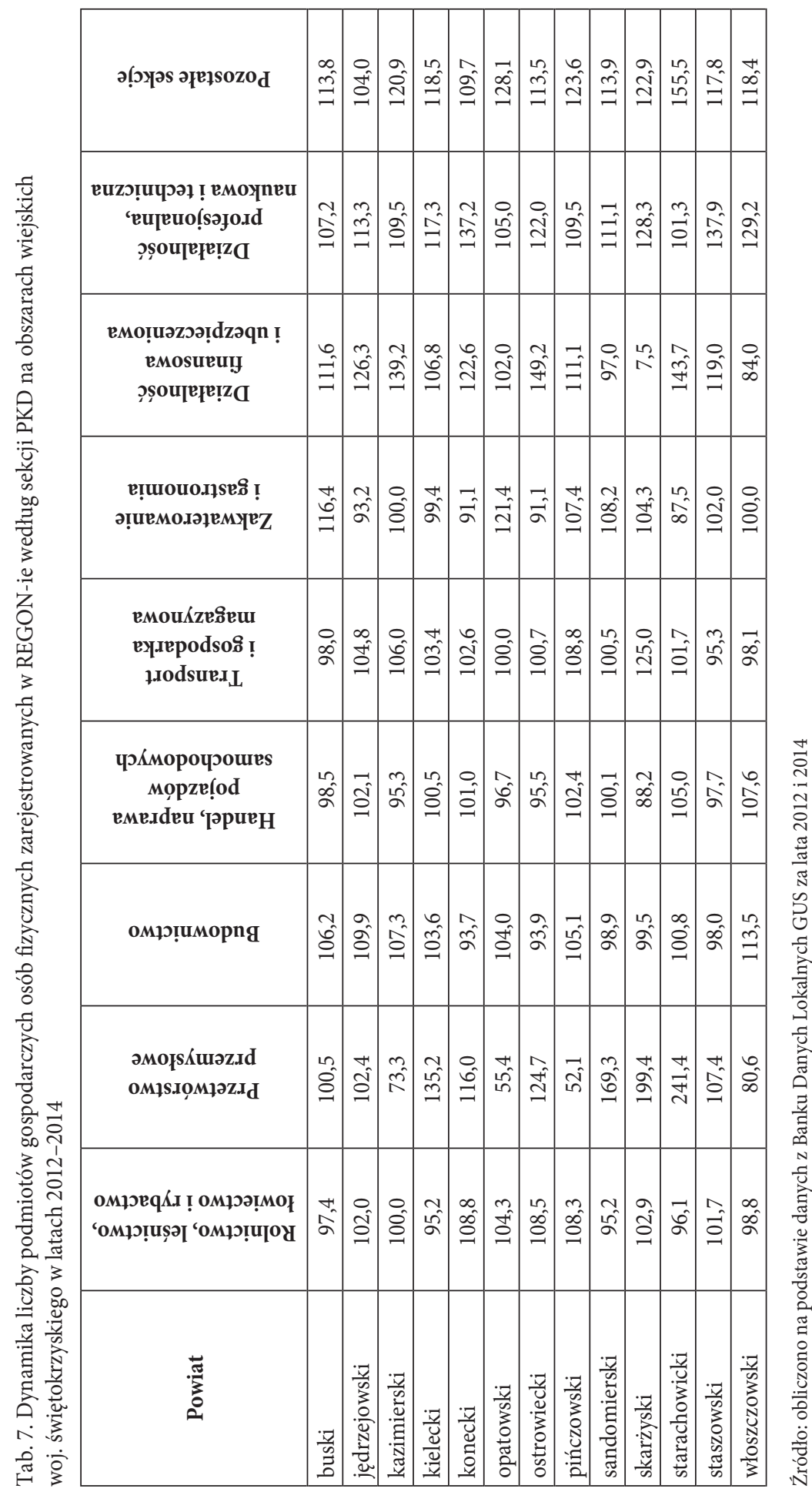


Wsparcie przedsiębiorczości ze środków funduszy krajowych i UE na przykładzie Regionalnego Programu Operacyjnego Województwa Świętokrzyskiego 2007-2013

Członkostwo Polski w Unii Europejskiej umożliwiło wszystkim kreatorom rozwoju, w tym samorządom i całej społeczności, dostęp do środków finansowych, które zostały skierowane na wsparcie działań potrzebnych do zniwelowania różnic rozwojowych pomiędzy regionami. Ważnym mechanizmem wsparcia jest Europejski Fundusz Rozwoju Regionalnego. Jednym z kompleksowych narzędzi realizacji polityki rozwoju jest dla województwa Regionalny Program Operacyjny Województwa Śląskiego 2007-2013 (RPOWŚ), którego założenia zmierzają do wzrostu konkurencyjności społeczno-gospodarczej oraz zwiększenia spójności terytorialnej w wymiarze ponadregionalnym (Wrońska-Kiczor, 2015). W celu przezwyciężenia barier rozwojowych przedsiębiorczości $\mathrm{w}$ regionie, $\mathrm{w}$ priorytetowej osi 1: Rozwój przedsiębiorczości, przewidziano bezpośrednie wsparcie inwestycyjne MŚ firm. Preferowane były projekty podmiotów działających w sektorze produkcyjnym i usługowym, w różnych branżach, przez realizację inwestycji generujących nowe miejsca pracy i wdrażające nowe, innowacyjne technologie i rozwiązania. Bezpośrednie dotacje przeznaczono na zakup nowych środków trwałych oraz wartości niematerialnych i prawnych. Większość przedsięwzięć miała charakter innowacyjny ${ }^{1}$, co poprawiło kondycję firm i podniosło ich konkurencyjność. Wsparcie finansowe skierowane na rozwój przedsiębiorczości wg RPOWŚ 2007-2013 było następujące:

Oś 1. Rozwój przedsiębiorczości: 585 umów na kwotę 349,6 mln €, w tym dofinansowanie z EFRR 125,4 mln € (tj. 99,3\% realizacji alokacji środków). Do końca 2014 r. zrealizowano 515 projektów z 585 podpisanych umów:

- w 287 mikroprzedsiębiorstwach, 151 małych i 61 średnich przedsiębiorstwach,

- 8 zrealizowanych przez grupy przedsiębiorstw;

- 8 zrealizowanych przez Instytucje Otoczenia Biznesu.

Od uruchomienia programu wpłynęły 3563 wnioski na kwotę 335,1 mln €. Wartość wykorzystania alokacji kształtuje się na poziomie 95,6\%. Na rzecz beneficjentów wypłacono 138,3 mln €. Efekty rzeczowe: ponad 2606 miejsc pracy.

W rozkładzie przestrzennym gmin najwięcej przedsięwzięć realizowali przedsiębiorcy z terenów podmiejskich Kielc i gmin miejsko-wiejskich. Zdecydowanie najniższe kwoty dotacji trafiły do gmin z przewagą funkcji rolniczej i położonych na terenach o niskim poziomie rozwoju infrastruktury drogowej i środowiskowej (ryc. 3).

Kolejne wsparcie dla MŚP było zawarte w działaniach osi priorytetowej 2: Wsparcie innowacyjności, budowa społeczeństwa informacyjnego oraz wzrost potencjału inwestycyjnego regionu. Wsparciem objęto przedsięwzięcia służące podniesieniu poziomu innowacyjności gospodarki regionu przez wzmocnienie potencjału sektora badawczo-rozwojowego dla rozwoju przedsiębiorczości, intensyfikację współpracy instytucji o charakterze badawczo-rozwojowym (w tym uczelni wyższych i specjalistycznych jednostek ochrony zdrowia) z przedsiębiorstwami, skutkujące zwiększeniem transferu nowoczesnych technik i technologii oraz umiejętności ich wykorzystania. Dofinansowywane były projekty dotyczące budowy i rozbudowy infrastruktury dostępu do Internetu. Wsparcia finansowe było następujące:

\footnotetext{
${ }^{1}$ Innowacja ma miejsce, gdy nowy lub ulepszony produkt zostaje wprowadzony na rynek albo nowy lub ulepszony proces zostaje zastosowany w produkcji, przy czym ów produkt i proces są nowe przynajmniej z punktu widzenia wprowadzającego je przedsiębiorstwa.
} 
Ryc. 3. Przestrzenne zróżnicowanie w wartości dotacji z funduszy UE na osobę w działaniach osi 1.

Przedsiębiorczość na terenach wiejskich regionu świętokrzyskiego wg RPOWŚ 2007-2013

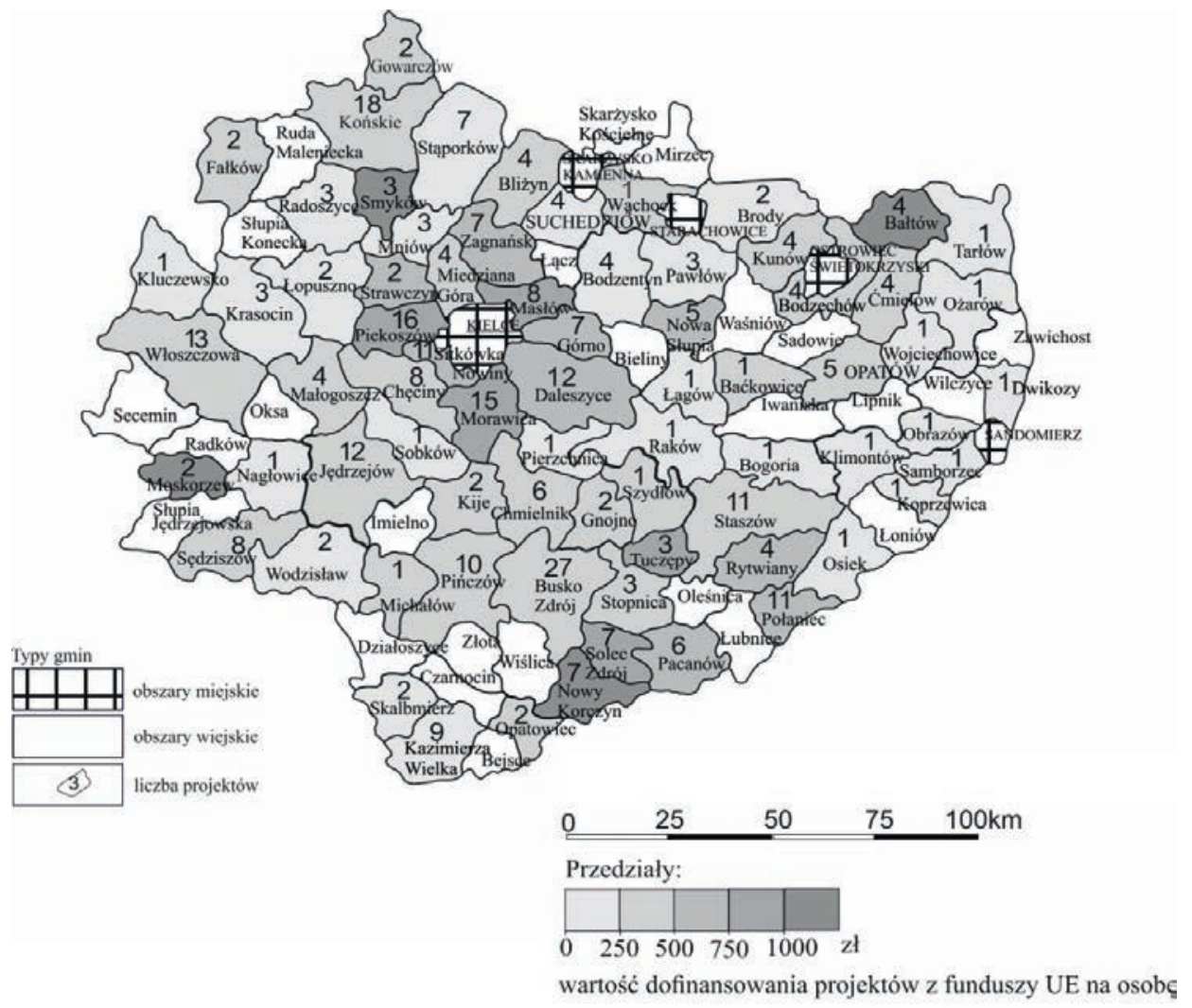

Źródło: opracowanie własne na podstawie danych z portalu www.rpo-swiętkrzyskie-mapa.pl

\section{Oś 2. Wsparcie innowacyjności, budowa społeczeństwa informacyjnego oraz wzrost po- tencjału inwestycyjnego regionu:}

121 umów na kwotę 123,2 mln €, w tym środki 122,9 mln € to środki z EFRR, co daje $100,24 \%$ ich realizacji. Do końca 2013 r. zrealizowano 83 projekty na kwotę $115,3 \mathrm{mln} €$, co daje 74,87\% realizacji zobowiązań UE na lata 2007-2013, w ramach tej osi.

$\mathrm{Na}$ obszarze badań w rozkładzie przestrzennym gmin realizacja przedsięwzięć była bardzo zróżnicowana (ryc. 4).

Najwyższe kwoty dofinansowania trafiły do większości gmin położonych z dala od miast i gmin miejsko-wiejskich, a najniższe do gmin położonych w północnej części regionu charakteryzujących się przewagą funkcji mieszanej przemysłowo-rolniczej.

W ramach priorytetowej osi 1 istotne wsparcie dla MŚP realizowano w ramach działania 1.3: Tworzenie i rozbudowa funduszy pożyczkowych i gwarancyjnych. Od $2010 \mathrm{r}$. działalność pożyczkowa dotyczyła 5 funduszy pożyczkowych, a działalność gwarancyjna - 2 funduszy poręczeniowych (31.08.2014 r.) (tab. 8). Przedsiębiorcom prowadzącym działalność gospodarczą udzielono 938 pożyczek na kwotę 134,4 mln zł i 137 poręczeń na kwotę 29,6 mln zł. 
Ryc. 4. Przestrzenne zróżnicowanie w liczbie i w wartości dotacji z funduszy UE na osobę w działaniach osi 2 na terenach wiejskich regionu świętokrzyskiego wg RPOWŚ 2007-2013

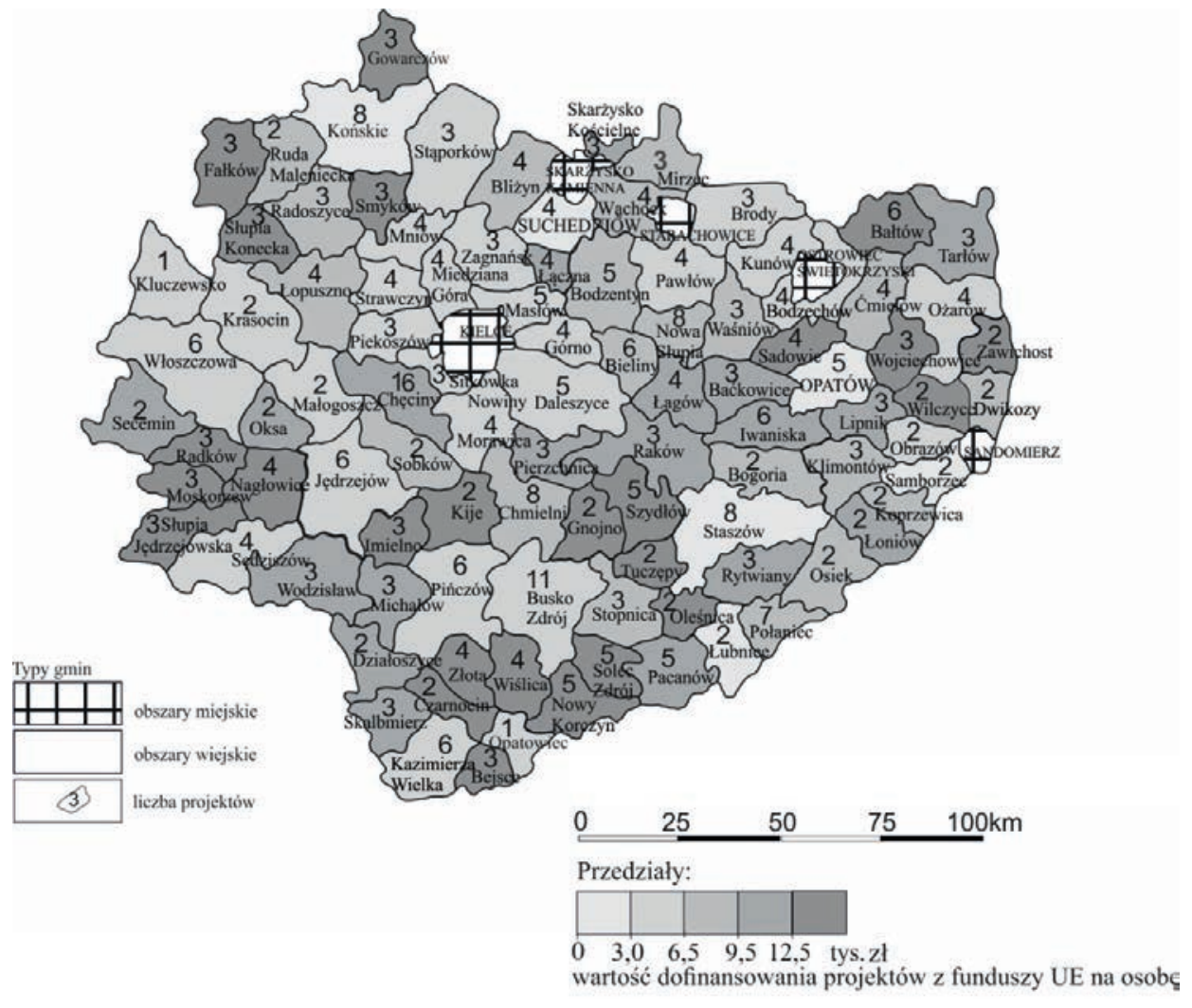

Źródło: opracowanie własne na podstawie danych z portalu www.rpo-swiętkrzyskie-mapa.pl

Najbardziej aktywny był fundusz pożyczkowy EUROSTAR 2. Większość pożyczek trafiła do mikrofirm (90\% w ujęciu ilościowym i 63,8\% w ujęciu wartościowym na koniec lipca 2014 r.). Udział małych przedsiębiorstw wyniósł odpowiednio 7,7\% i 2,3\%, zaś średnich - 2,3\% i 11,9\%. Średnia wartość pożyczki wyniosła: dla mikroprzedsiębiorcy 101,1 tys. zł, dla małego przedsiębiorcy - 449,3 tys. zł i dla średniego przedsiębiorcy - 754,6 tys. zł. Największą pulę pożyczek skierowano na inwestycje (43,5\% w ujęciu ilościowym i 51,2\% w ujęciu wartościowym). Znaczący był także udział pożyczek na zakup środków obrotowych (odp. 36,8\% i 38\%). Najmniejszy udział w strukturze wg przeznaczenia miały pożyczki o charakterze inwestycyjno-obrotowym (19,7\% i 10,8\%). Średnia wartość pożyczki inwestycyjnej to 168,1 tys. zł, obrotowej 147,2 tys. zł, zaś inwestycyjno-obrotowej 78,5 tys. zł. Z pożyczki najczęściej korzystali przedsiębiorcy działający w branży usługowej (44,7\% ilościowo i 42,7\% wartościowo) oraz handlowej (odp.: 37,4\% i 33,2\%). W dalszej kolejności były to branże: produkcyjna (13,2\% i $20,8 \%)$ i budownictwo (4,2\% i 2,7). Średnio najwyższą pożyczkę uzyskiwali przedsiębiorcy z branży przemysłowej - 92,8 tys. zł, z innych branż - 147,2 tys. zł. Najczęściej środki finansowe były przeznaczane na zakup środków trwałych (maszyn i urządzeń, linii technologicznej), 
realizację inwestycji budowlanych (w tym remonty, modernizacje) lub zakup nieruchomości itp. (Ocena ex-ante...).

Można stwierdzić, że najwyższe zainteresowanie środkami unijnymi było w podregionie sandomiersko-jędrzejowskim (29\% firm), a najniższe - w kieleckim (18\% firm).

Tab. 8. Wsparcie ze środków funduszy pożyczkowych i funduszy poręczycielskich dofinansowanych w ramach działania 1.3 RPOWŚ 2007-2013

\begin{tabular}{|c|c|c|c|c|}
\hline $\begin{array}{c}\text { Nazwa funduszu } \\
\text { pożyczkowego (FP) }\end{array}$ & $\begin{array}{c}\text { Wielkość } \\
\text { dofinansowania } \\
{[\mathrm{mln} \mathrm{zl}]}\end{array}$ & Liczba umów & $\begin{array}{c}\text { Wartość } \\
\text { podpisanych } \\
\text { umów }[\mathrm{mln} \mathrm{zl}]\end{array}$ & $\begin{array}{c}\text { Średnia } \\
\text { wartość } \\
\text { pożyczki }[\mathbf{z l}]\end{array}$ \\
\hline \multicolumn{5}{|l|}{ Fundusze pożyczkowe } \\
\hline $\begin{array}{l}\text { Województwa } \\
\text { Świętokrzyskiego Sp. z o.o. }\end{array}$ & 60,0 & 219 & 70,4 & 321676,0 \\
\hline Świętokrzyski & 25,4 & 386 & 40,7 & 105532,0 \\
\hline Lokalny & 12,6 & 200 & 13,5 & 67969,0 \\
\hline $\begin{array}{l}\text { Ośrodka Promowania } \\
\text { Przedsiębiorczości } \\
\text { w Sandomierzu }\end{array}$ & 8,7 & 96 & 6,8 & 71700,0 \\
\hline EUROSTAR 2 & 1,4 & 37 & 0,2 & 75281,0 \\
\hline \multicolumn{5}{|l|}{ Fundusze poręczycielskie } \\
\hline Światowy FP Sp. z o.o. & 27,0 & 110 & 2,5 & 230094,2 \\
\hline $\begin{array}{l}\text { Świętokrzyskie poręczenia } \\
\text { kredytowe i pożyczkowe }\end{array}$ & 6,0 & 27 & 4,3 & 159936,9 \\
\hline
\end{tabular}

Źródło: opracowanie własne na podstawie: Ocena ex-ante...(49-50)

\section{Podsumowanie}

Przedstawiona analiza pozwala stwierdzić, że:

- Od początku lat 90 ubiegłego wieku liczebność małych i średnich przedsiębiorstw na terenach wiejskich regionu świętokrzyskiego wzrosła ponad 36-krotnie, co świadczy o ich dużej randze w kształtowaniu struktury gospodarczej wsi, bowiem często tylko one tworzą pozarolnicze miejsca pracy.

- W latach 1999-2014 nastąpił wzrost aktywności gospodarczej osób fizycznych na terenach wiejskich. Iloraz lokalizacji wzrósł z 0,23 do 0,38.

- Większość MŚP na obszarach wiejskich jest powiązana z sektorem rolnictwa, co stanowi barierę związaną zarówno z czynnikami lokalizacyjnymi, dużym rozproszeniem, małą skalą działalności, słabymi rynkami zbytu, niskim poziomem rozwoju infrastruktury (komunikacyjnej i środowiskowej), jak i z aktywnością i poziomem wykształcenia mieszkańców wsi. Ponadto istotne bariery stanowią często brak własnych zasobów finansowych, skomplikowane procedury dzielności gospodarczej, nadmierny fiskalizm państwa wobec przedsiębiorstw, firm rodzinnych, trudności w pozyskiwaniu zewnętrznych środków na rozpoczęcie i rozwój firm.

- W latach 2007-2013 projekty realizowane w ramach RPOWŚ przyniosły już wiele efektów rzeczowych, inne są na etapie realizacji i będą widoczne niebawem, a jeszcze inne w nieodległej przyszłości. Obecnie wiele z nich ma pozytywny wymiar zwłaszcza na terenach 
zagrożonych depresją gospodarczą, położonych peryferyjnie ze znacznym zapóźnieniem infrastrukturalnym i słabo rozwiniętą działalnością pozarolniczą (Kiniorska, 2014).

- Kształtowanie się struktur rodzajowych w ramach pozarolniczej działalności gospodarczej będzie zależne przede wszystkim od czynników lokalnych i regionalnych. Naczelną rolę w aktywizacji społeczności i rozwoju wsi odgrywa tworzenie nowych miejsc pracy, inwestowanie pozyskanych środków w inwestycje związane z zakupem maszyn urządzeń lub ich modernizacją, tworzeniem nowych linii produkcyjnych itd. (Kiniorska, 2014).

- Jedynie upowszechnienie przedsiębiorczości na wsi świętokrzyskiej będzie receptą na poprawę sytuacji społeczno-ekonomicznej. Tworzenie miejsc pracy da dodatkowe źródła dochodów, zmniejszy bezrobocie, ubóstwo, patologie społeczne i ograniczy zjawisko wykluczenia społeczno-ekonomicznego. To jedyna droga do lepszego jutra.

Literatura

References

Bank Danych Lokalnych. GUS (2014, 10 września). Pozyskano z: www.stat.gov.pl

Charakterystyka gospodarstw rolnych w podregionach, powiatach igminach województwa Świętokrzyskiego - PSR 2010. Urząd Statystyczny w Kielcach, Kielce 2012.

Duczkowska-Piasecka, M. (1997). Małe i średnie przedsiębiorstwa na terenach wiejskich (ich rola, znaczenie oraz możliwości i bariery rozwojowe). W: M. Kłodziński i A. Rosner (red.), Ekonomiczne i społeczne uwarunkowania $i$ możliwości wielofunkcyjnego rozwoju wsi w Polsce. Warszawa: Wydawnictwo Naukowe SGGW.

Jaremczuk, K. (2003). Uwarunkowania rozwoju przedsiębiorczości - szanse i zagrożenia. Tarnobrzeg: Wydawnictwo Naukowe PWSzZ.

Jarosiński, J. Trafiałek, T. (2014). Mała i średnia przedsiębiorczość w systemie polityki społecznej regionu świętokrzyskiego. Studia Ekonomiczne, UE, Katowice.

Kamińska, W. (1993). Problematyka rozwoju struktur przestrzennych indywidualnej działalności gospodarczej w woj. kieleckim w procesie przechodzenia do gospodarki rynkowej. W: J. Kitowski, Z. Zioło (red.), Czynniki i bariery rozwoju regionów przygranicznych. Kraków - Rzeszów Warszawa, 201-213.

Kamińska, W. (1996). Rozwój i przemiany struktury przestrzennej indywidualnej działalności gospodarczej $w$ regionie kieleckim. Kielce: Wydawnictwo Naukowe WSzP.

Kiniorska, I. (2010). Przestrzenne zróżnicowanie struktury poziomu życia - ujęcie regionalne, W: J. Gruszczyński (red.), Infrastruktura i ekologia terenów wiejskich. PAN, Komisja Technicznej Infrastruktury Wsi. Kraków: Wydawnictwo Naukowe UR.

Kiniorska, I. (2014). Potencjał rozwojowy obszarów wiejskich woj. świętokrzyskiego a polityka spójności. W: W. Kamińska, K. Hoffner (red.), Polityka spójności a rozwój obszarów wiejskich. Stare problemy i nowe wyzwania PAN KPZK. Warszawa, t. CLVI, 358-378.

Makieła, Z. (2008). Przedsiębiorczość regionalna. Warszawa: Difin.

Ocena ex-ante instrumentów finansowych RPOWŚ 2014-2020. UM, Kielce (2015, 20 czerwca). Pozyskano z: www.wygpsdb.pl

Rachwał, T. (2005). Kształtowanie postaw uczniów na lekcjach przedsiębiorczości, Przedsiębiorczość Edukacja, 1, 137-143.

Raporty o stanie sektora MŚP w latach 1999-2014, PARP. Warszawa (2015, 5 czerwca). Pozyskano z: badania.pap.gov.pl.

Strojny, J. (2010). Analiza potencjału przedsiębiorczego województwa podkarpackiego. Przedsiębiorczość - Edukacja, 6, 176-197.

Sprawozdanie z Regionalnego Programu Operacyjnego Województwa Świętokrzyskiego 2007-2013. Urząd Marszałkowski, Kielce. 
www.rpo-swiętokrzyskie-mapa.pl

Wrońska-Kiczor, J. (2013). Rozdrobnione rolnictwo województwa świętokrzyskiego na przełomie XX i XXI wieku. Kielce: Wydawnictwo Naukowe UJK.

Wrońska-Kiczor, J. (2014). Potencjał gospodarczy województwa świętokrzyskiego. Miscellanea Oeconomicae Studia i Materialy, 3(14), 251-261.

Wrońska-Kiczor, J. (2015). Wpływ instrumentów polityki spójności UE na rozwój obszarów wiejskich Gór Świętokrzyskich. Miscellanea Oeconomicae Studia i Materiały, 4(15), 251-261.

Zioło, Z. (2007). Rola przedsiębiorczości w aktywizacji gospodarczej - zarys modelu. Przedsiębiorczość Edukacja, 3, 10-17.

Zioło, Z. (2008). Ekonomiczne i społeczne uwarunkowania rozwoju gospodarki opartej na wiedzy. Przedsiębiorczość - Edukacja, 4, 12-23.

Iwona Kiniorska, dr, zatrudniona w Zakładzie Geografii Społeczno-Ekonomicznej Instytutu Geografii Uniwersytetu Jana Kochanowskiego w Kielcach na stanowisku adiunkta. Doktor nauk o Ziemi w zakresie geografii. Zainteresowania badawcze autorki skupiają się wokół tematów: obszary zurbanizowane i wiejskie (warunki, poziom i jakość życia, nierówności społeczne) oraz przedsiębiorczość, turystyka wiejska i rozwój lokalny.

Iwona Kiniorska, $\mathrm{PhD}$, employed in the Department of Socio-Economic Geography, Institute of Geography of the Jan Kochanowski University in Kielce, as an adjunct (adiunkt). PhD of earth sciences in geography. Interested in urbanized and rural areas (conditions, living standards, quality of living, social inequalities) and entrepreneurship, tourism in rural areas and local development.

Janina Wrońska-Kiczor, dr inż., pracuje w Zakładzie Badań Regionalnych i Gospodarki Przestrzennej Instytutu Geografii Uniwersytetu Jana Kochanowskiego na stanowisku adiunkta. Doktor nauk rolniczych w zakresie agronomii. Zainteresowania badawcze autorki skupiają się wokół problematyki przekształceń strukturalnych w rolnictwie polski, ze szczególnym uwzględnieniem przemian struktury agrarnej, wielofunkcyjności wsi i rolnictwa oraz uwarunkowań przyrodniczych i społeczno-ekonomicznych obszarów wiejskich regionu świętokrzyskiego.

Janina Wrońska-Kiczor, PhD, Engineer, employed in the Department of Regional Studies and Spatial Planning, Institute of Geography of the Jan Kochanowski University in Kielce, as an adjunct (adiunkt). $\mathrm{PhD}$ of agricultural sciences in agronomy. Interested in structural changes in the Polish agriculture with special emphasis on changes in agrarian structure, multi-functionalism of rural areas, natural environmental as well as socio-economic conditions in rural areas of the Swietokrzyskie region.

\author{
Adres/Address: \\ Uniwersytet Jana Kochanowskiego \\ Instytut Geografii \\ ul. Świętokrzyska 15 \\ 25-406 Kielce, Polska \\ e-mail: lucy@ujk.edu.pl \\ e-mail: iwona.kiniorska@ujk.edu.pl
}

